Supplement of Sci. Dril., 28, 93-112, 2020

https://doi.org/10.5194/sd-28-93-2020-supplement

(c) Author(s) 2020. This work is distributed under

the Creative Commons Attribution 4.0 License.

(c) (1)

Supplement of

\title{
Report on ICDP Deep Dust workshops: probing continental climate of the late Paleozoic icehouse-greenhouse transition and beyond
}

Gerilyn S. Soreghan et al.

Correspondence to: Gerilyn S. Soreghan (1soreg@ou.edu)

The copyright of individual parts of the supplement might differ from the CC BY 4.0 License. 


\section{Major Topics to Investigate}

1- Equatorial paleoclimate of peak icehouse and icehouse collapse

2- Atmospheric dust and the Pangaean megamonsoon

3- The later Permian - Extremes leading up to the Great Dying

4- The character and extent of the modern and fossil deep microbial biosphere

5- Auxiliary Science- Red-bed sedimentology, Pangaea paleogeography, induced seismicity, tectonics, geothermal energy, hydrogeology, drilling engineering

\begin{tabular}{|c|c|c|}
\hline Questions & Major topic/s & Methods/Approaches \\
\hline $\begin{array}{l}\text { Did glaciation affect low latitudes? If so, } \\
\text { what were the altitudinal limits of } \\
\text { glaciation? }\end{array}$ & 1 & $\begin{array}{l}\text { Coring of uplands to assess presence of } \\
\text { ice-contact or periglacial indictors; } \\
\text { correlation to paleoshorelines. }\end{array}$ \\
\hline $\begin{array}{l}\text { LPIA deglaciation: What is the far-field } \\
\text { record (rate, effects), and what were the } \\
\text { drivers? If CO2 was a primary driver, what } \\
\text { caused its extreme drawdown and } \\
\text { subsequent rise on the scale of the entire } \\
\text { Permian)? What sources/sinks and } \\
\text { mechanisms can explain the magnitude } \\
\text { and frequency of glacial-interglacial CO2 } \\
\text { variations? Can we assess O2? }\end{array}$ & 1,3 & $\begin{array}{l}\text { Assemble pCO2 indicators (e.g. from } \\
\text { paleosols; fluid inclusions?); carbon- } \\
\text { cycle modeling incorporating dust- } \\
\text { fertilization effects, weathering effects } \\
\text { (on both long- and short timescales). }\end{array}$ \\
\hline $\begin{array}{l}\text { What role did mineral aerosols play in low- } \\
\text { latitude climate? Can we quantify dust } \\
\text { loading of the equatorial atmosphere, and } \\
\text { the effects? How does dust provenance } \\
\text { inform atmospheric circulation (w/ impact } \\
\text { on understanding the megamonsoon)? }\end{array}$ & $1,2,3$ & $\begin{array}{l}\text { Reconstruction of dust loading (mass } \\
\text { accumulation rates) by dating, } \\
\text { quantitative cyclostratigraphy; dust } \\
\text { provenance (detrital zircons, } \\
\text { geochemistry; anisotropy of magnetic } \\
\text { susceptibility); Fe geochemistry of dust } \\
\text { deposits }\end{array}$ \\
\hline $\begin{array}{l}\text { What were spatiotemporal patterns of } \\
\text { continental climate change- eg the } \\
\text { character and pace of proposed } \\
\text { eastwardly progressing aridification? }\end{array}$ & $1,2,3$ & $\begin{array}{l}\text { Indices of chemical weathering from } \\
\text { loess, paleosols; compilation of arid- } \\
\text { climate indicators; measurement of } \mathrm{Sr} \\
\text { isotopes; } \mathrm{E}-\mathrm{W} \text { correction. }\end{array}$ \\
\hline $\begin{array}{l}\text { Can we assess astronomical forcing of } \\
\text { tropical climate and hydroclimate from the } \\
\text { icehouse-greenhouse transition up toward } \\
\text { the Great Dying? Are there changes in } \\
\text { dominant periodicities, especially across } \\
\text { the major deglaciation? }\end{array}$ & $1,2,3$ & $\begin{array}{l}\text { Conduct quantitative cyclostratigraphy } \\
\text { throughout the cored successions. }\end{array}$ \\
\hline
\end{tabular}




\begin{tabular}{|c|c|c|}
\hline Questions & Major topic/s & Methods/Approaches \\
\hline $\begin{array}{l}\text { How does Fe reactivity in dust deposits } \\
\text { vary through time and (low latitude) space } \\
\text { (E-W equatorial)? }\end{array}$ & $1,2,3$ & $\begin{array}{l}\text { Measure Fe reactivity through the cored } \\
\text { intervals. }\end{array}$ \\
\hline $\begin{array}{l}\text { How extreme- in terms of hydroclimate, } \\
\text { temperature, and } \mathrm{pH} \text { (acidity) did } \\
\text { equatorial environments become? What } \\
\text { were the critical forcing factors (e.g. CO2, } \\
\text { aerosols, continental position, monsoon)? }\end{array}$ & 2 and 3 & $\begin{array}{l}\text { Assemble paleoclimate indicators, } \\
\text { especially extent of arid-climate proxies, } \\
\text { evaporite inclusions, organic } \\
\text { geochemistry, etc., and proxies for } \\
\text { atmospheric circulation (eg loess } \\
\text { provenance). }\end{array}$ \\
\hline $\begin{array}{l}\text { What drove the end-Guadalupian biotic } \\
\text { event? Is it related to climatic events? } \\
\text { Was it spatially diachronous? }\end{array}$ & 3 & $\begin{array}{l}\text { Assemble proxies and indicators for } \\
\text { temperature/aridity etc- - e.g. fluid } \\
\text { inclusions, clumped isotopes (of eg } \\
\text { pedogenic carbonate), weathering } \\
\text { indices, organic biomarkers, etc. } \\
\text { Correlate using e.g. palynofacies. }\end{array}$ \\
\hline $\begin{array}{l}\text { What is the extent of the (modern) } \\
\text { microbial biosphere? How deep? What } \\
\text { are the metabolic pathways for this life? } \\
\text { Are As and Fe involved? Hydrocarbons? }\end{array}$ & 4 & $\begin{array}{l}\text { Conduct clean sampling of pore fluids } \\
\text { during coring. }\end{array}$ \\
\hline $\begin{array}{l}\text { Can we document a fossil microbial } \\
\text { biosphere? What types of extremophiles } \\
\text { might have existed? Under what } \mathrm{pH} / \mathrm{temp} \\
\text { conditions? }\end{array}$ & 4 & $\begin{array}{l}\text { Examine fluid inclusions in, e.g. } \\
\text { evaporites. Document life forms, and } \\
\text { accompanying } \mathrm{pH} \text { and temperature } \\
\text { proxies. }\end{array}$ \\
\hline $\begin{array}{l}\text { What is the origin of red beds, especially } \\
\text { those formed far from localized } \\
\text { volcanism? Did the Permian atmosphere } \\
\text { promote iron reactivity? And/or O2 levels } \\
\text { (potentially obtainable via fluid } \\
\text { inclusions?) }\end{array}$ & 5 & $\begin{array}{l}\text { See above- measure Fe reactivity on } \\
\text { loess and dust-associated deposits. }\end{array}$ \\
\hline $\begin{array}{l}\text { Can we constrain uplift rates of the } \\
\text { Appalachian and Variscan orogens using } \\
\text { thermochronology? }\end{array}$ & 5 & $\begin{array}{l}\text { Conduct thermochronology through } \\
\text { cored intervals. }\end{array}$ \\
\hline $\begin{array}{l}\text { What are baseline values of modern states } \\
\text { such as geothermal gradients and micro } \\
\text { seismicity in the target basins? }\end{array}$ & 5 & Instrument the boreholes for monitoring. \\
\hline $\begin{array}{l}\text { What is magnetic behavior during a } \\
\text { superchron? Did orbital forcing affect } \\
\text { magnetic field behavior? }\end{array}$ & 5 & Cyclostratigraphy \\
\hline $\begin{array}{l}\text { What was the paleogeography of Pangea } \\
\text { during the Permian? Is it better captured } \\
\text { by Pangea A or Pangea B (or neither)? } \\
\text { What were the latitudes of the study sites, } \\
\text { and their continentality? }\end{array}$ & 5 & Paleomagnetism through the cores. \\
\hline
\end{tabular}

